\title{
INFLUENCE OF WATER DEFICIT AND SEASON ON BIOMASS YIELD FROM CLONAL STANDS OF EUCALYPTUS
}

\author{
Talita Miranda Teixeira Xavier ${ }^{1 *}$, José Eduardo Macedo Pezzopane ${ }^{1}$, Ricardo Miguel Penchel², \\ Marcos Vinicius Winckler Caldeira ${ }^{1}$, Edvaldo Fialho dos Reis ${ }^{1}$
}

*Corresponding author: talitamtx@yahoo.com.br

\begin{abstract}
This study aimed to analyze the influence of different levels of water deficit (DH) on initial seedling development of six clonal stands of hybrid Eucalyptus grandis $x$ E. urophylla in two seasons of the year. The experiment was conducted in the experimental site of UFES, in the municipality of Jerônimo Monteiro (ES), over two seasons: from February 9, 2009 to June 9, 2009 (season 1) and from July 11, 2009 to November 7, 2009 (season 2). In all experimental treatments, the first 30 days consisted of acclimating seedlings to the soils, which were thus irrigated. DH levels used in the experiment included: D0 - no water deficit; D1 - 90 days of water deficit; D2 - 60 days of water deficit followed by resumed irrigation for 30 days; D3 - 30 days of irrigation and 60 days of water deficit. The experiment was laid out in a completely randomized design, in subdivided plots (2x4), with four (4) levels of water deficit in the plot and two (2) seasons in the subplots, using three replications. Data on total dry matter of leaves, stem and branches, and root were subjected to analysis of variance and, if found significant, means were compared by the Tukey test at the 5\% probability level. The environmental conditions of season 1 favored dry matter yield from both clonal stands, while season 2, having milder climate conditions, failed to favor potential growth of seedlings, even with irrigation conditions being satisfactory. Different levels of water deficit gradually reduced dry matter yield, yet without following a pattern of reduction.
\end{abstract}

Key words: Water deficit, growth, Eucalyptus grandis $x$ Eucalyptus urophylla.

\section{INFLUÊNCIA DA RESTRIÇÃO HÍDRICA E ÉPOCA DE AVALIAÇÃo NA PRODUÇÃO DE BIOMASSA DE CLONES DE EUCALIPTO}

\begin{abstract}
RESUMO: Neste trabalho, objetivou-se analisar a influência de níveis de deficit hídrico (DH), sobre o crescimento inicial de mudas de seis clones do hibrido Eucalyptus grandis $x$ E. urophylla em duas épocas do ano. O experimento foi realizado na área experimental da UFES, no município de Jerônimo Monteiro, ES, em duas épocas: de 09/02/09 a 09/06/09 (época 1) e 11/07/09 a 07/11/09 (época 2). Em todos os tratamentos, os primeiros 30 dias de experimento foram o período de aclimatação das mudas ao solo e, portanto, ambos eram irrigados. Os niveis de DH foram: D0: sem deficit; D1): 90 dias de DH; D2: 60 dias de DH e retomada da irrigação por mais 30 dias e D3: 30 dias de irrigação e 60 dias de DH. O delineamento experimental utilizado foi o inteiramente ao acaso, em parcelas subdivididas $2 \times 4$, sendo os quatro (4) niveis de DH na parcela e as duas (2) épocas nas subparcelas, com três repetições. Os dados de matéria seca total, de folhas, de haste e ramos e raiz foram submetidos à análise de variância, e quando significativas, as médias foram comparadas pelo teste de média Tukey, a 5\% de probabilidade. As condições ambientais da época 1 favoreceram a produção de matéria seca dos dois clones e a época 2 com condições climáticas mais amenas não proporcionou o crescimento potencial das mudas, nem mesmo em condições irrigadas satisfatoriamente. Os níveis dos deficit reduziram a produção de matéria seca de maneira gradativa, porém sem seguir um padrão de redução.
\end{abstract}

Palavras-chave: Deficit hídrico, crescimento, Eucalyptus grandis x Eucalyptus urophylla.

\section{INTRODUCTION}

Environmental factors have major influence on plant life, expressing the climate conditions of a particular region and thus determining whether it is suitable or not for cultivation of a given species (PEREIRA et al., 2002).

Marengo (2007) raises the possibility of droughts intensifying in southeastern Brazil, while Baesso et al. (2006) prognosticate a possible $24 \%$ to $40 \%$ reduction in eucalyptus productivity. Many studies have been conducted in order to evaluate the effects of environmental

${ }^{1}$ Universidade Federal do Espírito Santo - Alegre, Espírito Santo, Brazil

${ }^{2}$ Fibria Celulose S.A. - Jacareí, São Paulo, Brazil factors on biomass yield in nonnative forests of eucalyptus (GONÇALVES; PASSOS, 2000; LANE et al., 2004; LI et al., 2000).

A reduction in soil water availability can cause damage to plant life (LARCHER, 2006), leading to changes in the way plants grow which could be even irreversible (SANTOS; CARLESSO, 1998). In such context, the capability with which crops use water stored in the soil, in association with meteorological factors that interact with their shoot portion, can influence the supply of water to plants (CARLESSO, 1995). Therefore, water

Cerne, Lavras, v. 19, n. 3, p. 473-479, jul./set. 2013 
transfer in the soil-plant-atmosphere system can vary widely conditional on season of the year, species and time of the day (MARENCO; LOPES, 2007).

Eucalyptus crops are often established in locations with high atmospheric demand and sparse, irregular rates of annual rainfall, which jeopardizes both the success and productivity of crops. However, the influence of different planting seasons, characterized by distinct climate conditions, on the strength of eucalyptus seedlings to withstand water stress is a topic not sufficiently addressed. In an attempt to fill that void, this study was aimed at evaluating the influence of water deficit on initial seedling development of two clonal stands of eucalyptus, in two different planting seasons.

\section{MATERIAL AND METHODS}

\subsection{Characteristics of the study site and plant material}

The experiment was conducted in an experimental site of the Forest Engineering Department of UFES, municipality of Jerônimo Monteiro (ES), located at coordinates $20^{\circ} 47^{\prime} 25^{\prime \prime}$ south latitude and $41^{\circ} 23^{\prime} 48^{\prime \prime}$ west longitude, at an altitude of $120 \mathrm{~m}$, throughout two planting seasons, namely February 9 to June 9, 2009 (season 1) and July 11 to November 7, 2009 (season 2).

Evaluations were made on seedlings of two elite and commercial genotypes (Clone 01 and Clone 02) of hybrid Eucalyptus grandis $x$ Eucalyptus urophylla. Seedlings 90 days old were selected and transplanted into soil-filled pots $42 \mathrm{~cm}$ in diameter, $72 \mathrm{~cm}$ in height and with a capacity of around $100 \mathrm{dm}^{3}$.

Upon chemical analysis of the soil, fertilization was applied throughout each experimental season, consisting of 150 g.dm ${ }^{-3}$ of NPK (04-16-04), 100 g.dm ${ }^{-3}$ of NPK $(00-18-00)+20$ g. $\mathrm{dm}^{-3}$ of micronutrients. The fertilizers were diluted in water and applied to each pot.

\subsection{Experimental design and setup}

The experiment was conducted in open air, adopting a spacing of $2 \times 2 \mathrm{~m}$ between pots. Seedlings were left to grow in the pots for a period of 30 days (acclimation), with moisture close to field capacity, after which time they started to be subjected to water deficit levels (DH) through to the end of the experiment, each totaling 120 days (Figure 1).

The soil field capacity was determined for later use in calculating the water depth in order to irrigate each of the treatments. The following water deficit levels were used: Deficit 0 (D0) - moisture kept close to field capacity

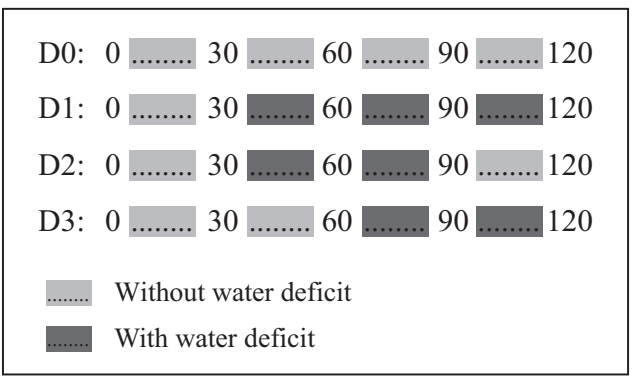

Figure 1 - Levels of water deficit during the experimental periods.

Figura 1 - Niveis dos deficit hídrico durante os periodos experimentais.

throughout the entire experimental period; Deficit 1 (D1) once seedlings were acclimatized, irrigation was suspended through to the end of the experiment (90 days of water deficit); Deficit 2 (D2) - once seedlings were acclimatized, irrigation was suspended for 60 days and then resumed for another 30 days (60 days of water deficit); Deficit 3 (D3) - once seedlings were acclimatized, irrigation was maintained for another 30 days ( 60 days of irrigation) and then suspended for 60 days ( 60 days of water deficit).

The experiment was laid out in a completely randomized design, in subdivided plots $(2 \times 4)$, applying 4 levels of water deficit $\left(\mathrm{D}_{0}, \mathrm{D}_{1}, \mathrm{D}_{2}\right.$ and $\left.\mathrm{D}_{3}\right)$ to the plot and 2 seasons (Season 1 and Season 2) to the subplots, with three replications. Experimental data were subjected to analysis of variance and, if found significant, the means were compared by the Tukey test at the 5\% probability level.

\subsection{Characteristics evaluated}

\subsubsection{Microclimate}

For acquiring microclimate data, an automatic weather station was installed in an open air area close to the experiment, under standard conditions and avoiding plant interference during data collection. Equipment mounted in the station included: CS500 temperature and relative humidity sensors, a Par Lite photosynthetically active radiation sensor, a 03002 Wind Sentry Set wind speed sensor and a TR-525M rain gauge, coupled to a CR - 10X datalogger programmed to read data collected every 10 seconds and store averages every 15 minutes.

\subsubsection{Dry matter accumulation}

In the final stage of the experiment, on day 120 , three plants were selected at random from each treatment and subjected to analysis to obtain the dry matter of leaves, 
stem and branches, roots and total dry matter. Plant parts were placed in a forced air oven set at $70^{\circ} \mathrm{C}$ for at least 72 hours, after which time they were weighed to obtain the dry weight.

\subsubsection{Water availability and water depth}

A drip irrigation system was adopted, using one dripper per pot with a flow rate of approximately 6 liters/hour. At the start of the experiment, the pots were saturated and left to drain freely. In order to stabilize moisture and determine the water depth, the following equations were used (SALASSIER et al., 2005):

$I R N=\frac{(C C-U a) D s Z}{10}$

$I T N=\frac{I R N}{E a}$

where: $\mathrm{IRN}=$ actual irrigation requirement, in $\mathrm{mm} ; \mathrm{CC}=$ field capacity, in \%; Ua = current moisture, in $\%$; Ds $=$ soil density, in g. $\mathrm{cm}^{3} ; \mathrm{Z}=$ root system depth, in $\mathrm{cm} ; \mathrm{ITN}=$ total irrigation requirement, in $\mathrm{mm} ; \mathrm{Ea}=$ irrigation application efficiency $(90 \%)$.

\subsubsection{Soil water storage}

Monitoring of soil water storage was done by daily calculating the climatic water balance using data on precipitation and irrigation according to the levels of water deficit and potential evapotranspiration as estimated by the Penman-Monteith method.

\section{RESULTS AND DISCUSSION}

\subsection{Characterization of climate conditions and soil water storage throughout the two experimental seasons}

Microclimate data pointed to Season 1 as having greater energy availability, particularly in the first 60 days of the experiment. Season 2, on the other hand, was characterized as a period of milder conditions. Consequently, Season 1 was found more favorable to plant growth and thus more conducive to the initial development of eucalyptus seedlings than Season 2 was.

Considering both experimental seasons, there was no decrease in the soil water storage as a function of deficit levels being imposed, as was expected, on some periods (Figure 2). This was due to occurrence of precipitation events which raised the soil water content. Yet there was no distortion of water deficit levels altogether, with a significant difference remaining between them.
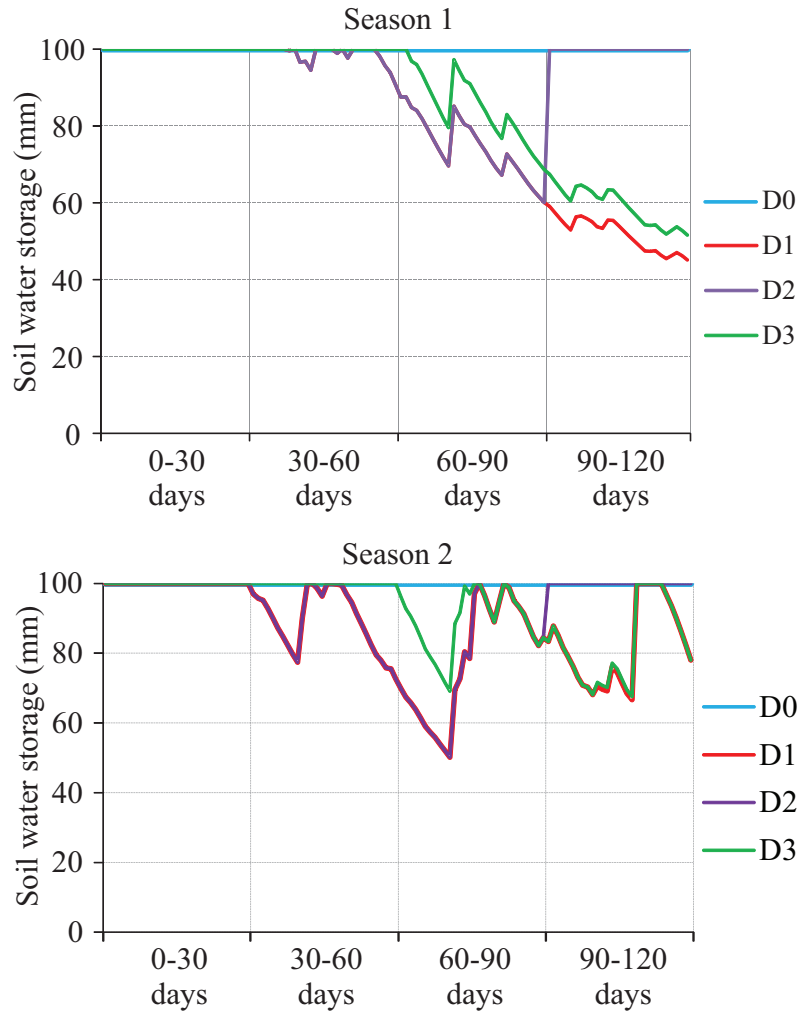

Figure 2 - Soil water storage throughout the two experimental seasons under different water deficit levels, namely D0 - no deficit, D1 - deficit 1, D2 - deficit 2, D3 - deficit 3.

Figura 2 - Armazenamento de água no solo durante as duas épocas experimentais sob diferentes níveis de deficit hídrico, (D0) - sem deficit, (D1) - deficit 1, (D2) - deficit 2, (D3) - deficit 3.

\subsection{Productivity of each clonal stand individually}

\subsubsection{Clone 1}

For the variables total dry matter, leaf dry matter and root dry matter (Table 1), the deficit x season interaction was significant, in both seasons. In assessing the effect of season, the means found for all variables in all deficit levels were statistically higher in Season 1 than in Season 2, with the exception of level D0 for root dry matter.

Regarding the effect of water deficit levels on total dry matter, in both experimental seasons, analysis revealed a statistically significant difference for D0 only, higher than the rest. Therefore, reduction in total dry matter occurred independently from the deficit level, revealing a difference only when compared to the constantly irrigated level. This demonstrates that both in D2, with resumed irrigation, and in D3, with a longer acclimation period, plants failed to

Cerne, Lavras, v. 19, n. 3, p. 473-479, jul./set. 2013 
Table 1 - Total dry matter, leaf dry matter and root dry matter of plants from clonal stand 1, as a function of the seasons for each deficit level (row) and as a function of the deficit levels for each season (column), in Jerônimo Monteiro (ES), 2009.

Tabela 1 - Matéria seca total, de folhas e de raiz das plantas do clone 1, em função das épocas de avaliação para cada nível de deficit hídrico (linha) e em função dos deficit hídrico para época de avaliação (coluna), em Jerônimo Monteiro-ES, 2009.

\begin{tabular}{|c|c|c|c|c|c|c|c|c|c|c|c|c|}
\hline \multirow{3}{*}{$\begin{array}{c}\text { Deficit } \\
\text { D0 }\end{array}$} & \multicolumn{4}{|c|}{ Leaf dry matter (g) } & \multicolumn{4}{|c|}{ Root dry matter (g) } & \multicolumn{4}{|c|}{ Total dry matter (g) } \\
\hline & \multicolumn{2}{|c|}{ season 1} & \multicolumn{2}{|c|}{ season 2} & \multicolumn{2}{|c|}{ season 1} & \multicolumn{2}{|c|}{ season 2} & \multicolumn{2}{|c|}{ season 1} & \multicolumn{2}{|c|}{ season 2} \\
\hline & 211.49 & $\mathrm{Aa}$ & 179.14 & $\mathrm{Ab}$ & 431.39 & $\mathrm{Aa}$ & 446.65 & $\mathrm{Aa}$ & 958.58 & $\mathrm{Aa}$ & 828.53 & $\mathrm{Ab}$ \\
\hline D1 & 132.3 & $\mathrm{Ba}$ & 13.46 & $\mathrm{Bb}$ & 88.57 & $\mathrm{Ca}$ & 5.3 & $\mathrm{Bb}$ & 381.68 & $\mathrm{Ba}$ & 48.35 & $\mathrm{Bb}$ \\
\hline D2 & 100.32 & $\mathrm{Ca}$ & 13.40 & $\mathrm{Bb}$ & 127.1 & $\mathrm{BCa}$ & 7.51 & $\mathrm{Bb}$ & 415.3 & $\mathrm{Ba}$ & 45.68 & $\mathrm{Bb}$ \\
\hline D3 & 139.99 & $\mathrm{Ba}$ & 28.9 & $\mathrm{Bb}$ & 160.86 & $\mathrm{BCa}$ & 21.21 & $\mathrm{Bb}$ & 486.33 & $\mathrm{Ba}$ & 132.38 & $\mathrm{Bb}$ \\
\hline
\end{tabular}

* Means followed by the same capital letter (deficit) vertically and small letter (season) horizontally do not differ by the Tukey test at the $5 \%$ probability level

reach their potential of dry matter accumulation. However, the possibility that precipitation in the relevant period may have influenced the result should not be ruled out.

It is understood that Season 1, unlike Season 2, was very favorable to dry matter yield by offering adequate climate conditions which, in association with soil water storage, favored total dry matter yield from plants.

As regards leaf dry matter (Table 1), in Season 1 the deficit level D0 was statistically higher than levels D1 and D3, which were statistically similar to each other but differed from D2. In Season 2 the deficit level D0 was higher than the rest, while D1, D2 and D3 were statistically similar. Lopes et al. (2007) found that shoot dry matter increased in plants of Eucalyptus grandis 108 days old the greater the irrigation water depth was.

As for root dry matter (Table 1), in Season 1 the deficit level D0 was statistically higher than the rest, followed by D2 and D3 which were similar to each other but higher than D1. In Season 2, deficit levels D1, D2 and D3 did not differ from one other and had means significantly lower than level D0.

Lopes et al. (2007) found that root dry matter gradually increased to the extent that the irrigation water depth was increased. According to Kozlowski (2002), some plants take longer to fully develop their roots once seedlings have been planted. Hence, if evaluated shortly after planted, their roots will still be underdeveloped and thus unable to absorb the amount of water required to compensate for water loss through transpiration.

With regard to dry matter of stem and branches, no significant interaction was found between water deficit $\mathrm{x}$ season, as evaluated separately (Table 2). Season 1 was statistically higher than Season 2. Regarding deficit levels, level D0 was significantly different from other levels,
Table 2 - Stem and branch dry matter of plants from clonal stand 1 , as a function of water deficit levels (a) and as a function of evaluation seasons (b), at the end of the experiment, in Jerônimo Monteiro (ES), 2009.

Tabela 2 - Matéria seca de haste e ramos das plantas do clone 1, em função dos níveis de deficit hídrico (a) e em função das épocas de avaliação (b), no final do experimento, em Jerônimo Monteiro-ES, 2009.

\begin{tabular}{ccc}
\hline Deficit & \multicolumn{2}{c}{ Stem and branch dry matter } \\
\hline a) & 259.21 & $\mathrm{~A}$ \\
D1 & 133.87 & $\mathrm{~B}$ \\
D2 & 106.29 & $\mathrm{~B}$ \\
D3 & 95.20 & $\mathrm{~B}$ \\
\hline & & \\
\hline & & \\
\hline Season & Stem and branch dry matter \\
\hline Season 1 & 212.49 & $\mathrm{~A}$ \\
Season 2 & 84.82 & $\mathrm{~B}$ \\
\hline
\end{tabular}

which in turn were not statistically different from one another. According to Larcher (2006), an increase in dry matter occurs when carbon is not consumed by respiration and instead is used for plant development, hence why in Season 1 plants may have yielded more dry matter.

Figure 3 illustrates the differential distribution of dry matter in different plant organs (leaf, stem and branches, and root) for each water deficit level. It was found, in both seasons, that the root compartment contributed the most toward total dry matter at the end of the experiment for D0. However, as water deficit levels were imposed, the biomass distribution changed in both seasons, with the compartments stem and branches contributing the most toward plant dry matter.

Cerne, Lavras, v. 19, n. 3, p. 473-479, jul./set. 2013 

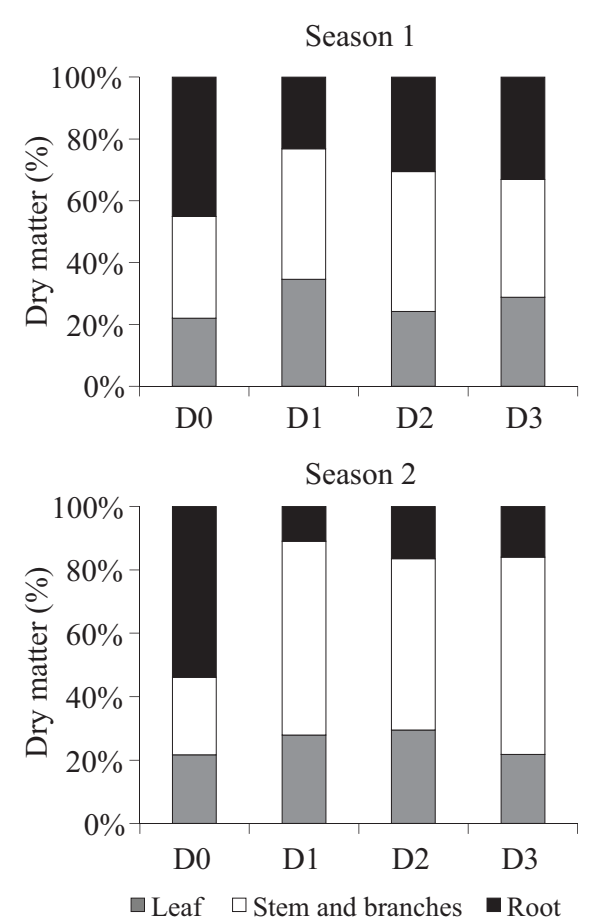

Figure 3 - Dry matter (\%) of leaves, stem and branches, and roots in plants from clonal stand 1 during Season 1 (FebruaryJune 2009) and Season 2 (July-November 2009), under different water deficit levels, namely D0 - no deficit, D1 - deficit 1, D2 deficit 2, D3 - deficit 3.

Figura 3-Matéria seca (\%) de folhas, haste e ramos, e raiz das plantas do clone 1, durante a época 1 (fevereiro-junho de 2009) e a época 2 (julho-novembro de 2009), sob diferentes níveis de deficit hidrico, D0 - sem deficit, (D1) - deficit 1, (D2) - deficit 2, (D3) - deficit 3.
It was found that both water deficiency and planting season significantly influenced the yield and distribution of dry matter in different plant portions, indicating that the growth rates of clonal stand 1 can be induced by environment-imposed conditions.

\subsubsection{Clone 2}

For the variables total dry matter, leaf dry matter, stem and branch dry matter, and root dry matter (Table 3), the deficit $x$ season interaction was significant. Dry matter data demonstrate that season was indeed an important factor for dry matter yield, with Season 1 being statistically higher than Season 2, in all levels of water deficit and for all variables being assessed, and thus proving more suitable for accumulation of dry matter.

Upon analysis of the effect of different deficit levels on total dry matter, in Season 1 it was found that level D0 was higher than the others. Level D3 was lower than D0 but higher than D1 and D2. Level D1 in turn was higher than D2. In Season 2, level D0 was statistically higher than the others, while level D3 was higher than D1 and D2, which in turn were statistically similar.

Also in Table 3, now evaluating leaf dry matter under influence of different water deficit levels, it was found in Season 1 that level D0 was statistically higher than the rest. Level D3 was lower than D0 but higher than D1 and D2, which in turn were similar. In Season 2, level D0 was higher than all others for that variable.

As regards stem and branch dry matter (Table 3 ) in Season 1, level D3 statistically differed from other levels, level D0 was statistically lower than D3 but higher than

Table 3 - Total dry matter, leaf dry matter, stem and branch dry matter, and root dry matter of plants from clonal stand 2, as a function of the seasons for each deficit level (row) and as a function of the deficit levels for each season (column) in Jerônimo Monteiro (ES), 2009.

Tabela 3 - Matéria seca total, de folhas, de haste e ramos e de raiz das plantas do clone 2, em função das épocas de avaliação para cada nível de deficit hídrico (linha) e em função do deficit hídrico para cada época experimental (coluna), em Jerônimo Monteiro-ES, 2009.

\begin{tabular}{|c|c|c|c|c|c|c|c|c|c|c|c|c|c|c|c|c|}
\hline \multirow{3}{*}{$\begin{array}{c}\text { Deficit } \\
\text { D0 }\end{array}$} & \multicolumn{4}{|c|}{ Leaf dry matter $(\mathrm{g})$} & \multicolumn{4}{|c|}{ Root dry matter (g) } & \multicolumn{4}{|c|}{ Stem and branch dry matter $(\mathrm{g})$} & \multicolumn{4}{|c|}{ Total dry matter $(\mathrm{g})$} \\
\hline & \multicolumn{2}{|c|}{ season 1} & \multicolumn{2}{|c|}{ season 2} & \multicolumn{2}{|c|}{ season 1} & \multicolumn{2}{|c|}{ season 2} & \multicolumn{2}{|c|}{ season 1} & \multicolumn{2}{|c|}{ season 2} & \multicolumn{2}{|c|}{ season 1} & \multicolumn{2}{|c|}{ season 2} \\
\hline & 321.4 & $\mathrm{Aa}$ & 118.5 & $\mathrm{Ab}$ & 311.8 & $\mathrm{Aa}$ & 196.5 & $\mathrm{Ab}$ & 304.5 & $\mathrm{Ba}$ & 113.5 & $\mathrm{Ab}$ & 937.8 & $\mathrm{Aa}$ & 428.6 & $\mathrm{Ab}$ \\
\hline D1 & 106.9 & $\mathrm{Ca}$ & 13.01 & $\mathrm{Bb}$ & 117.2 & $\mathrm{Ba}$ & 3.25 & $\mathrm{Bb}$ & 167.6 & $\mathrm{Da}$ & 32.81 & $\mathrm{Bb}$ & 391.7 & $\mathrm{Da}$ & 49.1 & $\mathrm{Cb}$ \\
\hline $\mathrm{D} 2$ & 98.7 & $\mathrm{Ca}$ & 13.1 & $\mathrm{Bb}$ & 237.16 & $\mathrm{Aa}$ & 7.33 & $\mathrm{Bb}$ & 233.1 & $\mathrm{Ca}$ & 22.33 & $\mathrm{Bb}$ & 568.9 & $\mathrm{Ca}$ & 42.7 & $\mathrm{Cb}$ \\
\hline D3 & 212.5 & $\mathrm{Ba}$ & 49.8 & $\mathrm{Bb}$ & 137.8 & $\mathrm{Ba}$ & 53.5 & $\mathrm{Bb}$ & 411.9 & $\mathrm{Aa}$ & 99.12 & $\mathrm{Ab}$ & 761.9 & $\mathrm{Ba}$ & 202.4 & $\mathrm{Bb}$ \\
\hline
\end{tabular}

*Means followed by the same capital letter (deficit) vertically and small letter (season) horizontally do not differ by the Tukey test at the $5 \%$ probability level.

Cerne, Lavras, v. 19, n. 3, p. 473-479, jul./set. 2013 
levels D2 and D1, which in turn did not differ. In Season 2, deficit levels D0 and D3 were significantly higher than D1 and D2.

As for root dry matter, it was also found that application of deficit levels influenced that variable, noting that in Season 1 levels D0 and D2 were statistically higher than other levels, while levels D1 and D3 were statistically similar. In Season 2, level D0 was statistically higher than the rest.

The above validates that resumption of irrigation as imposed by level D2 in that season was sufficient for plants to restart their root development, and even though level D3 maintained soil water close to field capacity in the first 60 days, the interruption in irrigation imposed in the final 60 days was sufficient to prevent plants from reaching their potential dry matter rates.

The yield of dry matter from plants subjected to deficit level D3 was statistically higher in comparison to level D2, and may be explained by the fact that plants grown under suitable conditions of water supply are usually less resistant to water deficits and so if they are suddenly subjected to a condition of water stress, their morphophysiological mechanisms become severely affected (SANTOS; CARLESSO, 1998). Perhaps the decrease in root dry matter may be also attributed to continuous renewal of roots in environments subjected to water deficit.

The percentage of dry matter yielded by each plant part in relation to total dry matter (Figure 4) implies that, in Season 1 the plant compartments contributed similarly toward the total dry matter accumulated in level D0. It can be thus said that, where water availability is sufficient to meet plant requirements, in the early stage of seedling development the dry matter is equally distributed among plant organs.

In plants subjected to deficit levels D1 and D2, the organ contributing the least toward total dry matter was the leaves, while stem and branches along with roots contributed similarly. In plants subjected to level D3, stem and branches was the primary sink. When a plant is prematurely subjected to moderate conditions of water deficit, there is a tendency for leaves to shed, and so stem and branches become the organ contributing the most.

In Season 2, for deficit level D0, the plant organ contributing the most toward total dry matter was roots. This is explained by the fact that the environmental conditions of that season did not favor fast growth, causing the plant to commit more of its photoassimilate resources to root development in order to better adapt to the soil,
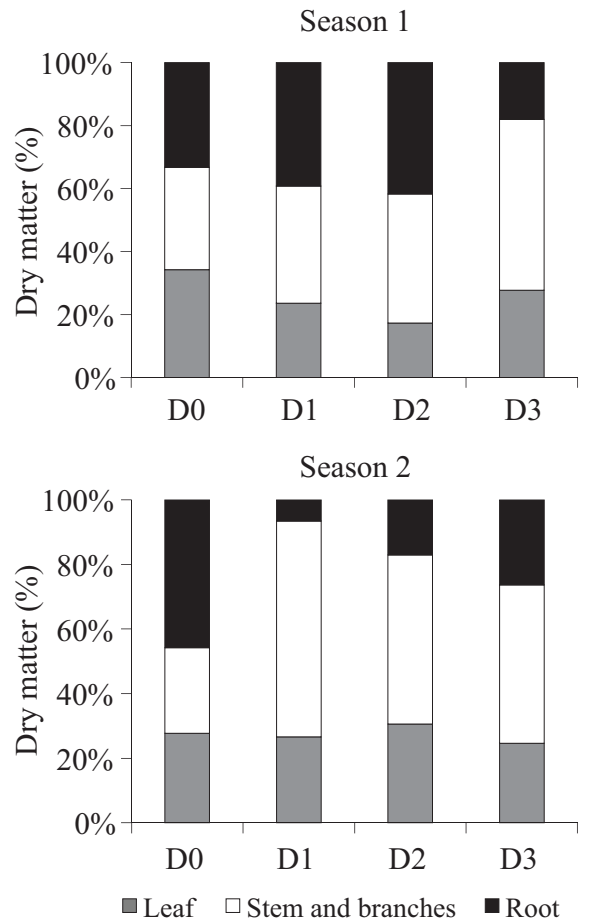

Figure 4 - Dry matter (\%) of leaves, stem and branches, and roots in plants from clonal stand 2, at the end of the experiment, in Season 1 (February-June 2009) and Season 2 (July-November 2009), under different water deficit levels, namely D0 - no deficit, D1 - deficit 1, D2 - deficit 2, D3 - deficit 3.

Figura 4-Matéria seca (\%) de folhas, haste e ramos, e raiz das plantas do clone 2, no final do experimento, durante a época 1 (fevereiro-junho de 2009) e época 2 (julho-novembro de 2009), sob diferentes niveis de deficits hídricos, DO - sem deficit, (D1)deficit 1, (D2) - deficit 2, (D3) - deficit 3.

capturing water from deeper soil layers, as reported by Taiz and Zeiger (2008). As for deficit levels D1, D2 and D3, the greatest contribution was provided by stem and branches. It was inferred that this may be due to substantial shedding of leaves and renewal of roots, in an attempt to tolerate such stressful condition.

\section{CONCLUSIONS}

In Season 1, the environmental conditions favored dry matter yield from both clonal hybrids of Eucalyptus grandis $x$ Eucalyptus urophylla. In Season 2, however, the environmental conditions failed to favor potential seedling development even with adequate water supply. Yet it should be noted that the roots developed considerably under such conditions in an attempt to better adapt to the soil. 
The water deficit levels applied in this study gradually reduced dry matter yield, though they did not follow a pattern of reduction as a function of the water deficit period.

\section{REFERENCES}

BAESSO, R. C. E.; RIBEIRO, A.; SILVA, M. P. Impacto das mudanças climáticas na produtividade do eucalipto na região norte do espírito santo e sul da Bahia. Ciência Florestal, Santa Maria, v. 20, n. 2, p. 335-344, 2010.

CARLESSO, R. Absorção de água pelas plantas: água disponível versus extraível e a produtividade das culturas. Ciência Rural, Santa Maria, v. 25, n. 1, p. 183-188, jan./fev. 1995.

GONÇALVES, M. R.; PASSOS, C. A. M. Crescimento de cinco espécies de eucalipto submetidos a déficit hídrico em dois níveis de fósforo. Ciência Florestal, Santa Maria, v. 10, n. 2, p. 145-161, 2000.

KOSLOWSKI, T. T. Acclimation and adaptive responses of woody plants to environmental stresses. The Botanical Review, Bronx, v. 68, n. 2, p. 270-334, 2002.

LANE, P. N. J.; MORRIS, J.; NINGNAN, Z.; GUANGYI, Z.; GUOYI, Z.; DAPING, X. Water balance of tropical eucalypt plantations in south-eastern China. Agricultural and Forest Meteorology, Amsterdam, v. 124, p. 253-267, 2004.

LARCHER, W. Ecofisiologia vegetal. 3. ed. São Carlos: Rima, 2006. 531 p.
LI, C.; BERNINGER, F.; KOSKELA, J.; SONNINEN, E. Drought responses of Eucalyptus microtheca provenances depend on seasonality of rainfall in their place of origin. Australian Journal of Plant Physiology, Victoria, v. 27, n. 3, p. 231-238, 2000 .

LOPES, J. L. W.; GUERRINI, I. A.; SAAD, J. C. C. Qualidade de mudas de eucalipto produzidas sob diferentes lâminas de irrigação e dois tipos de substrato. Revista Árvore, Viçosa, v. 31, n. 5, p. 835-843, set./out. 2007.

MARENCO, R. A.; LOPES, N. F. Fisiologia vegetal: fotossíntese, respiração, relações hídricas e nutrição mineral. Viçosa, MG: UFV, 2007. 451 p.

MARENGO, J. A. Caracterização do clima no século XX e cenários climáticos no Brasil e na América do Sul para o Século XXI, derivados dos modelos globais de clima do IPCC: relatório 1. Brasília: Ministério do Meio Ambiente, 2007. 181 p.

PEREIRA, A. R.; ANGELOCCI, L. R.; SENTELHAS, P. C. Agrometeorologia: fundamentos e aplicações práticas. Guaíba: Agropecuária, 2002. 478 p.

SALASSIER, B.; SOARES, A. A.; MANTOVANI, E. C. Manual de irrigação. 7. ed. Viçosa, MG: UFV, 2005. 611 p.

SANTOS, R. F.; CARLESSO, R. Déficit hídrico e os processos morfológico e fisiológico das plantas. Revista Brasileira de Engenharia Agrícola Ambiental, Campina Grande, v. 2, n. 3, p. 287-294, 1998.

TAIZ, L.; ZEIGER, E. Fisiologia vegetal. 4. ed. Porto Alegre: Artmed, 2008. 719 p.

Received: May 25, 2011; accepted: March 25, 2013.

Cerne, Lavras, v. 19, n. 3, p. 473-479, jul./set. 2013 
